\title{
Food Consumption and Nutrient Density of Adults Male Aged 19-49 Years Old in Indonesia
}

\author{
Teguh Jati Prasetyo ${ }^{1}$, Izzati Nur Khoiriani ${ }^{1}$, Katri Andini Surijati ${ }^{1}$ \\ ${ }^{1}$ Departement of Nutrition, Faculty of Health Sciences, Jenderal Soedirman University, \\ Purwokerto, Indonesia. \\ Correspondence: teguhjatiprasetyo@unsoed.ac.id
}

\begin{abstract}
The objectives of this study was to analyze food consumption and nutrient density of adults male aged 19-49 years old in Indonesia. This study was carried out through analyzing a consumption data set of Total Diet Study (SDT) of Indon esian Ministry of Health which were collected using 24-hour food recall method. The final subjects included for this study were 26268 male. The nutrients adequacy were assessed based on Institute of Medicine calculation. The nutrients analyzed include energy, protein, calcium, iron, zinc, vitamin A and vitamin C. The average food consumption of Indonesian adult male population is mostly from the grains food group of $305.0 \mathrm{~g}$. The food group that was consumed the least by the adult population was oily seeds as much as $18.1 \mathrm{~g}$. The adequacy of energy, protein, calcium, iron, zinc, vitamin A and vitamin C were $81.4 \%, 108.3 \%, 105.5 \%, 159.4 \%, 64.8 \%, 107.7 \%$ and $54.6 \%$, respectively. The nutrient density of protein, $\mathrm{Ca}, \mathrm{Zn}$, vitamin $\mathrm{A}$ and vitamin $\mathrm{C}$ were still under the recommendation. It means that food consumption quality of Indonesian adults need to be improved. Considering the inadequate intake of some micronutrients in Indonesian adults male, it is necessary to increase the consumption of animal food, legumes, fruits and vegetables as sources of micronutrients.
\end{abstract}

Keywords: adult male, food consumption, nutrient density, and nutritional adequacy 


\section{INTRODUCTION}

Quality, healthy and productive Human Resources (HR) is influenced by the consumption of a variety of foods that are sufficient and balanced to meet the body's nutrition (1). The nutritional needs of each individual are influenced by age, activity, economic level, education level, ecology, and government policy. Adequacy of the body's nutrition is influenced by a good diet, which contains staple foods, side dishes, fruits and vegetables consumed in sufficient quantities in accordance with needs so that it can suffice sources of energy, builders and regulating substances (2).

The quality of food consumption in Indonesia is still low and less diversified because it is still dominated by carbohydrate sources, especially grains as the largest portion of each meal portion. Humans need more than 40 types of nutrients to be able to live actively and healthy but there is no one type of food that can meet all the nutritional needs (21). The quality of food consumption will affect the nutritional status and health status in the future, especially the age of 1949 years which is a productive age but the need for certain food consumption limits to maintain health $(6,17)$.

The quality of food consumption is related to nutrient density, which are foods that are high in nutrition but relatively low in calories. Nutrient-dense foods contain complex carbohydrates, lean proteins, healthy fats, vitamins and minerals (15). The density of energy and nutrients of food consumption can determine and measure the adequacy of energy intake and nutrition of each individual (9). Current dietary trends that focus on protein sources or energy sources only (16). Nutrition density approaches can be an important tool for nutrition education as well as a reference as a dietary guide (7). The density of energy and nutrients of food consumption can form consumption patterns and show the quality of food consumed.

Assessment of the quality of food consumption so far is only for household and regional scales using SKMI data and there has never been researched on individuals so research is needed to analyze food consumption and nutrient density for. This research is expected to be able to describe food consumption and nutrient density in adults so that it is expected to be able to provide information and evaluation on food consumption patterns and balanced nutrition intake to meet nutritional adequacy in adults in Indonesia.

\section{METHODS}

\section{Design, location and time}

The data used in this study was secondary data obtained from the Individual Food Consumption Survey (SKMI) which is part of the 2014 Total Diet Study (SDT). SDT was conducted by Ministry of Health 
of the Republic of Indonesia. SDT was the national survey in Indonesia that collects complete data on individual consumption. This study used a cross sectional study design that included 191524 individuals in 51127 households in all provinces and districts/cities in Indonesia. A survey of individual food consumption was carried out in 2014. The processing, analysis and interpretation of the data was carried out from March to June 2020 at the Nutrition Study Program, Faculty of Health Sciences, Jenderal Soedirman University, Purwokerto.

\section{Number and Subject Selection}

The population of Individual Food Consumption Survey or SKMI 2014 were provinces in Indonesia that were represented in household samples. Household samples were randomly selected from census block (BS) that have been visited and registered by Riskesdas 2013. Inclusion criteria of SKMI 2014 were all household samples and available household members when the data collected. Households that were cannot be visited and household members whose refuse to participate were excluded. The SKMI data included 191.524 people from 51.127 households spreaded across 2.080 census bloks, adult male aged 19 to 49 years were selected for analizing. The analysis used the total subjects data, namely 26.268 adult Indonesian males.

\section{Data Collection}

Criteria for this study included adult males 19 to 49 years old who were in fit condition, has normal daily intake (not fasting, no current dieting, and not sick). Data sample has cleaned for incomplete body weight and food intake data. This study analyzed Nutrient intake and adequacy level (compared to requirement data from Institut of Medicine) in adult men, using food consumption and nutrient intake data. The variables and variable category available in Tabel.1.

\section{Table 1: Variables dan Variable Category of} the Study

\begin{tabular}{|c|c|}
\hline Variables & Variable Category \\
\hline Body weight & $\begin{array}{l}\text { According to body weight of } \\
\text { subject (SKMI, 2014) }\end{array}$ \\
\hline $\begin{array}{l}\text { Food } \\
\text { Consumption }\end{array}$ & $\begin{array}{l}\text { According to type of food } \\
\text { consumption from subject } \\
\text { (SKMI, 2014) }\end{array}$ \\
\hline Nutrient Intake & $\begin{array}{l}\text { Makronutrient intake such as } \\
\text { energy, protein, fat and } \\
\text { carbohydrate }\end{array}$ \\
\hline $\begin{array}{l}\text { Nutrient } \\
\text { Adequacy Level }\end{array}$ & $\begin{array}{l}\text { According to category of age } \\
\text { and gender }\end{array}$ \\
\hline Nutrient Density & $\begin{array}{l}\text { 1. Adequate } \\
\text { 2. Inadequate }\end{array}$ \\
\hline
\end{tabular}

\section{Processing and analyzing of the Data}

The data processing stages consist of cleaning, categorizing and analyzing data. The data were obtained then processed using Microsoft Excel 2019 and analyzed using SPSS 23. Consumption of food sources of nutrients was analyzed by type of food, quantity (grams) and level of consumer participation. Based on the food 
consumption data, type of food consumption and nutrient intake are calculated. The calculation of the nutrient adequacy level is obtained from the comparison of intake with the needs of each nutrient according to the modified individual nutritional needs based on IOM (Table 2) for each age and sex category with the following formula:

$$
\text { Nutrient Adequacy }(\%)=\frac{\text { Nutrient Intake } \times 100 \%}{\text { Nutritional Need }}
$$

Table 2: Nutritional needs for each age group

\begin{tabular}{|c|c|c|c|c|c|c|}
\hline Sex-age group & $\begin{array}{c}\text { Body } \\
\text { weight }\end{array}$ & $\begin{array}{c}\mathrm{Ca} \\
(\mathrm{mg})\end{array}$ & $\begin{array}{c}\mathrm{Fe} \\
(\mathrm{mg})\end{array}$ & $\begin{array}{c}\mathbf{Z n} \\
(\mathbf{m g})\end{array}$ & $\begin{array}{l}\text { VitA } \\
\text { (ug) }\end{array}$ & $\begin{array}{l}\text { VitC } \\
\text { (mg) }\end{array}$ \\
\hline \multicolumn{7}{|l|}{ Men } \\
\hline $19-29$ years & 60 & 676.1 & 9.1 & 7.9 & 528.2 & 63.4 \\
\hline $30-49$ years & 62 & 698.6 & 9.4 & 8.2 & $545 . \S$ & 65.5 \\
\hline \multicolumn{7}{|l|}{ Women } \\
\hline $19-29$ years & 54 & 732.2 & 12.9 & 6.2 & $457 . t$ & 54.9 \\
\hline $30-49$ years & 55 & 745.8 & 13.1 & 6.3 & 466.1 & 55.9 \\
\hline
\end{tabular}

Calculation of energy used equation of Henry (2005), while to calculate the protein based on modified energy, protein, fat and carbohydrate adequacy calculation by IOM. Not only nutrient adequacy level from food consumption, but nutrient adequacy from individual also conceived in nutrient density. The nutrient density concept used to describe nutrient adequacy of food consumption diet individually apart from nutrient adequacy level. Based on score of energy density and food nutrient, it used to reference for food consumption to increase nutrient adequacy level and nutrient density at the end (8). The definition of nutrient density is comparison the amount of nutrient intake daily consumption per $1000 \mathrm{kkal}$ of energy (5). In addition the calculation of nutrient density is used the formula $(5,8,14)$ :

$$
\text { Nutrient Density }=\frac{\text { Nutrient Intake }}{\text { Energy Intake }} \times 1000
$$

The value of density nutrient intake classified to be inadequate if the nutrient density value is less than FAO standard and adequate if nutrient density value equal or more than FAO standard.

Table 3: Standard of Nutrient Density Intake

\begin{tabular}{lc}
\hline \multicolumn{1}{c}{ Zat Gizi } & Densita s \\
\hline Protein & $40-50 \mathrm{~g}$ \\
Calcium & $500-800 \mathrm{mg}$ \\
Iron & $7-40 \mathrm{mg}$ \\
Zink & $12-20 \mathrm{mg}$ \\
Vitamin C & $50-60 \mathrm{mg}$ \\
Vitamin A & $700-1000 \mu \mathrm{g}$ \\
\hline
\end{tabular}

Adapted by Drewnowski2005

\section{RESULTS}

\section{Socio-economic characteristics}

The socio-economic characteristics in this study include the area of residence, level of education, main occupation, and economic status showed in table 4. The descriptive statistical test shows that the majority of Indonesian men aged 19-49 years live in rural areas with a percentage of $55.7 \%$. Most of the male population graduated from high school (34\%). Most of Indonesia's adult males work as farmers $(27.6 \%)$. Most of the male population has upper middle economic status with a percentage of $21.7 \%$. 
Table 4: Distribution of subjects a ccording to socio-economic characteristics

\begin{tabular}{|c|c|c|c|}
\hline $\begin{array}{l}\text { Sosio- } \\
\text { Economic } \\
\end{array}$ & $\begin{array}{l}19-29 \\
\text { Years } \\
\end{array}$ & $\begin{array}{l}30-49 \\
\text { Years } \\
\end{array}$ & Total \\
\hline \multicolumn{4}{|l|}{ Wilayah } \\
\hline \multirow[t]{2}{*}{ Urban } & 3813 & 7836 & 11649 \\
\hline & $(47.6)$ & $(42.9)$ & (44.3) \\
\hline \multirow[t]{2}{*}{ Rural } & 4196 & 1042 & 14619 \\
\hline & $(52.4)$ & $3(57.1)$ & $(55.7)$ \\
\hline \multicolumn{4}{|l|}{$\begin{array}{l}\text { Education } \\
\text { level }\end{array}$} \\
\hline Not school & $582(7.3)$ & $\begin{array}{r}2279 \\
(12.5)\end{array}$ & $\begin{array}{r}2861 \\
(10.9)\end{array}$ \\
\hline \multirow{2}{*}{$\begin{array}{l}\text { Elementary } \\
\text { school }\end{array}$} & 1428 & 5608 & 7036 \\
\hline & (17.8) & $(30.7)$ & $(26.8)$ \\
\hline \multirow{2}{*}{$\begin{array}{l}\text { Junior High } \\
\text { School }\end{array}$} & 1749 & 3664 & 5413 \\
\hline & $(21.8)$ & $(20.1)$ & $(20.6)$ \\
\hline \multirow{2}{*}{$\begin{array}{l}\text { Senior High } \\
\text { School }\end{array}$} & 3634 & 5286 & 8920 \\
\hline & (45.4) & $(29.0)$ & $(34.0)$ \\
\hline \multirow{2}{*}{$\begin{array}{l}\text { Higher } \\
\text { education }\end{array}$} & $616(7.7)$ & 1422 & 2038 \\
\hline & & $(7.8)$ & $(7.8)$ \\
\hline \multicolumn{4}{|l|}{ Occupation } \\
\hline \multirow[t]{2}{*}{ Not work } & 1596 & 468 & 2064 \\
\hline & (19.9) & $(2.6)$ & (7.9) \\
\hline \multirow[t]{2}{*}{ Civil servant } & $126(1.6)$ & 1351 & 1477 \\
\hline & & $(7.4)$ & $(5.6)$ \\
\hline \multirow[t]{3}{*}{ Employee } & 1214 & 2004 & 3218 \\
\hline & (15.2) & $(11.0)$ & (12.3) \\
\hline & 1095 & 3979 & 5074 \\
\hline Entrepreneur & (13.7) & $(21.8)$ & (19.3) \\
\hline \multirow[t]{2}{*}{ Farmer } & 1282 & 5979 & 7261 \\
\hline & $(16.0)$ & $(32.7)$ & $(27.6)$ \\
\hline \multirow[t]{2}{*}{ Fisherman } & $160(2.0)$ & 606 & 766 \\
\hline & & $(3.3)$ & $(2.9)$ \\
\hline \multirow[t]{2}{*}{ Laborer } & 1268 & 2957 & 4225 \\
\hline & (15.8) & (16.2) & (16.1) \\
\hline \multirow[t]{2}{*}{ Other } & 1268 & 917 & 2183 \\
\hline & $(20.0)$ & $(5.0)$ & $(8.3)$ \\
\hline \multicolumn{4}{|l|}{$\begin{array}{l}\text { Economic } \\
\text { Status }\end{array}$} \\
\hline \multirow[t]{2}{*}{ Lowest } & 1444 & 3373 & 4817 \\
\hline & (18.0) & (18.5) & (18.3) \\
\hline Lower & 1550 & 3595 & 5145 \\
\hline Middle & $(19.4)$ & (19.7) & (19.6) \\
\hline \multirow[t]{2}{*}{ Middle } & 1750 & 3734 & 5484 \\
\hline & $(21.9)$ & $(20.5)$ & (20.9) \\
\hline \multirow{2}{*}{$\begin{array}{l}\text { Upper } \\
\text { Middle }\end{array}$} & 1782 & 3912 & 5694 \\
\hline & $(22.2)$ & $(21.1)$ & $(21.7)$ \\
\hline \multirow[t]{2}{*}{ Highest } & 1483 & 3645 & 5128 \\
\hline & $(18.5)$ & $(20.0)$ & $(19.5)$ \\
\hline
\end{tabular}

\section{Food Consumption of Adult Male in}

\section{Indonesia}

Table 5 shows that overall food consumption in the study subjects came from grains, tubers, animal foods, oils and fats, oily fruits/seeds, legumes, sugar, vegetables and fruits, and others. The highest consumption level in subjects aged $19-49$ years is grain with a total value of 305.0305140 .0 , the smallest level of food consumption in subjects aged 19-25 years is sugar with an average value of $15.4 \pm 18$ while the smallest level of food consumption at age $30-49$ years are oily fruits/seeds with an average value of $16.9 \pm 64.1$.

Table 5: Average (standard deviation) and median (participation rate) of food consumption according to 9 food groups and age groups

\begin{tabular}{lccc}
\hline $\begin{array}{l}\text { Food } \\
\text { group }\end{array}$ & $19-29$ years & $30-49$ years & Total \\
\hline \multicolumn{4}{c}{ Mean $\pm \mathrm{SD}$ (median $/ \%)$} \\
\hline Grains & $303.2 \pm 134.0$ & $305.8 \pm 142.6$ & $305.0 \pm 140.0$ \\
& $(150.0 / 99.2)$ & $(155.0 / 99.1)$ & $(150.0 / 99.2)$ \\
Tubers & $22.8 \pm 214.6$ & $28.3 \pm 238.5$ & $26.7 \pm 231.8$ \\
& $(34.0 / 20.7)$ & $(40.0 / 22.1)$ & $(38.0 / 21.7)$ \\
Animal & $158.2 \pm 113.0$ & $159.4 \pm 118.5$ & $159.0 \pm 116.8$ \\
food & $(72.6 / 82.7)$ & $(72.0 / 81.9)$ & $(72.0 / 82.1)$ \\
Oil and fat & $19.4 \pm 16.0$ & $20.1 \pm 16.8$ & $19.8 \pm 16.6$ \\
& $(15.0 / 91.2)$ & $(15.1 / 91.1)$ & $(15.0 / 91.1)$ \\
Oily & $16.9 \pm 64.1$ & $18.6 \pm 66.1$ & $18.1 \pm 65.5$ \\
fruits/seeds & $(40.0 / 27.6)$ & $(39.9 / 29.7)$ & $(40.0 / 29.0)$ \\
Legumes & $42.7 \pm 70.2$ & $44.7 \pm 74.6$ & $44.1 \pm 73.3$ \\
& $(50.0 / 41.9)$ & $(52.0 / 41.4)$ & $(50.1 / 41.5)$ \\
Sugar & $15.4 \pm 18.7$ & $21.2 \pm 21.2$ & $19.4 \pm 20.7$ \\
& $(15.0 / 67.9)$ & $(20.0 / 78.1)$ & $(20.0 / 75.0)$ \\
Vegetables & $80.3 \pm 59.5$ & $97.0 \pm 64.0$ & $91.9 \pm 62.8$ \\
and Fruits & $(20.8 / 85.2)$ & $(25.0 / 87.5)$ & $(24.0 / 86.8)$ \\
Other & $54.5 \pm 54.5$ & $45.7 \pm 38.1$ & $48.4 \pm 43.5$ \\
& $(2.8 / 99.1)$ & $(3.0 / 99.2)$ & $(3.0 / 99.1)$ \\
\hline
\end{tabular}

\section{Nutritional Intake And Nutritional}

\section{Adequacy Level}

Table 6 presents mean and median of nutrient intakes and nutrient adequacy based on age group in Indonesian adults male. Overall, male nutrient intakes aged 30-49 years were slightly higher than aged 19-29 years except for vitamin A. Mean of nutrient adequacy of indonesian male adult grouped by age are also presented ini table 6 . It can be clear that mean of nutrient adequacy 
showed the same pattern, in which greater than those aged 19-29 years in calcium and vitamin $\mathrm{C}$ adequacy.

Table 6: Mean (median), standard deviation (coefficient of variation) of nutritional intake and level of nutritional adequacy by age group

\begin{tabular}{|c|c|c|c|}
\hline Nutrients & $\begin{array}{l}19-29 \\
\text { years } \\
\end{array}$ & $30-49$ years & Total \\
\hline \multirow[t]{3}{*}{ Energy } & 1800 & $1852(1776)$ & 1836 \\
\hline & (1704) & $687(0.4)$ & (1755) \\
\hline & $699(0.4)$ & & $691(0.4)$ \\
\hline \multirow[t]{3}{*}{ Protein } & $64.6(59.7)$ & $66.4(61.8)$ & 65.9 \\
\hline & $31.8(0.5)$ & $32.5(0.5)$ & (61.1) \\
\hline & & & $32.3(0.5)$ \\
\hline \multirow[t]{4}{*}{$\mathrm{Ca}$} & 689.9 & 747.8 & 730.2 \\
\hline & (619.8) & (673.1) & (658.2) \\
\hline & $356.4(0.5)$ & $379.2(0.5)$ & 373.4 \\
\hline & & & $(0.5)$ \\
\hline \multirow[t]{3}{*}{$\mathrm{Fe}$} & $14.7(13.3)$ & $14.9(13.5)$ & 14.8 \\
\hline & $7.3(0.5)$ & $7.2(0.5)$ & (13.5) \\
\hline & & & $7.2(0.5)$ \\
\hline \multirow[t]{2}{*}{$\overline{Z n}$} & $5.2(4.5)$ & $5.3(4.6)$ & $5.3(4.5)$ \\
\hline & $3.1(0.6)$ & $3.3(0.6)$ & $3.3(0.6)$ \\
\hline \multirow[t]{4}{*}{ Vit A } & 589.6 & 578.7 & 582.0 \\
\hline & (427.7) & $(414.0)$ & (418.7) \\
\hline & $509.7(0.9)$ & $508.1(0.9)$ & 506.6 \\
\hline & & & $(0.9)$ \\
\hline \multirow[t]{3}{*}{ Vit C } & $31.2(19.5)$ & $37.3(23.6)$ & 35.5 \\
\hline & $36.9(1.2)$ & $41.8(1.1)$ & (22.3) \\
\hline & & & $40.5(1.1)$ \\
\hline \multirow[t]{3}{*}{$\mathrm{E}$} & $79.7(75.3)$ & $82.2(78.7)$ & 81.4 \\
\hline & $31.7(0.4)$ & $30.9(0.4)$ & (77.6) \\
\hline & & & $31.2(0.4)$ \\
\hline \multirow[t]{3}{*}{$\mathrm{P}$} & 110.8 & $107.2(98.8)$ & 108.3 \\
\hline & (100.9) & $53.7(0.5)$ & (99.5) \\
\hline & $56.1(0.5)$ & & $54.4(0.5)$ \\
\hline $\mathrm{Ca}$ & 102.0 & $107.0(96.3)$ & 105.5 \\
\hline \multirow[t]{2}{*}{ adequacy } & (91.7) & $54.3(0.5)$ & (95.0) \\
\hline & $52.7(0.5)$ & & $53.9(0.5)$ \\
\hline $\mathrm{Fe}$ & 161.4 & 158.6 & 159.4 \\
\hline \multirow[t]{2}{*}{ adequacy } & (145.6) & (143.8) & (144.3) \\
\hline & $80.1(0.5)$ & $76.6(0.5)$ & $77.6(0.5)$ \\
\hline $\mathrm{Zn}$ & $65.4(56.8)$ & $64.5(55.6)$ & 64.8 \\
\hline \multirow[t]{2}{*}{ adequacy } & $39.7(0.6)$ & $40.5(0.6)$ & (56.0) \\
\hline & & & $40.2(0.6)$ \\
\hline Vit A & 111.6 & $106.0(75.8)$ & 107.7 \\
\hline \multirow[t]{2}{*}{ adequacy } & (81.0) & $93.1(0.9)$ & (77.4) \\
\hline & $96.5(0.9)$ & & $94.2(0.9)$ \\
\hline Vit C & $49.2(30.8)$ & $57.0(36.1)$ & 54.6 \\
\hline \multirow[t]{2}{*}{ adequacy } & $58.3(1.2)$ & $63.8(1.1)$ & (34.4) \\
\hline & & & $62.3(1.1)$ \\
\hline
\end{tabular}

\section{Nutrient Density}

Nutrient density was the nutrient content in $1000 \mathrm{kcal}$ of subject energy. Based on the results of the analysis, it was known that the density protein, calcium, zinc, vitamin $\mathrm{C}$ and vitamin A were still below the recommendation so they were categorized as deficient. Only iron density was in accordance with recommendations.

Table 7: Mean, median, standard deviation and coefficient of variation in nutrient density of adult male by age group

\begin{tabular}{lrrr}
\hline Densitas & $\mathbf{1 9 - 2 9}$ & $\mathbf{3 0 - 4 9}$ & Total \\
Gizi & Years & \multicolumn{1}{c}{ Years } & \\
\hline \multicolumn{4}{c}{ Mean (median) } \\
standard deviation (coefficient of variation) \\
\hline Protein & 36.5 & 36.3 & 36.3 \\
density & $(34.6)$ & $(34.5)$ & $(34.5)$ \\
& 11.58 & 11.6 & 11.6 \\
& $(0.3)$ & $(0.3)$ & $(0.3)$ \\
\hline Ca density & 399.4 & 418.0 & 412.3 \\
& $(371.4)$ & $(383.8)$ & $(380.5)$ \\
& 186.5 & 192.5 & 190.9 \\
& $(0.5)$ & $(0.5)$ & $(0.5)$ \\
\hline Fe density & 8.4 & 8.3 & 8.3 \\
& $(7.6)$ & $(7.4)$ & $(7.5)$ \\
& 4.1 & 4.1 & 4.1 \\
& $(0.5)$ & $(0.5)$ & $(0.5)$ \\
\hline Zn density & 2.9 & 2.8 & 2.8 \\
& $(2.7)$ & $(2.6)$ & $(2.6)$ \\
& 1.3 & 1.4 & 1.4 \\
& $(0.5)$ & $(0.5)$ & $(0.5)$ \\
\hline Vit A & 340.8 & 323.7 & 328.9 \\
density & $(249.3)$ & $(233.6)$ & $(238.3)$ \\
& 311.7 & 299.4 & 303.3 \\
Vit C & $(0.9)$ & $(0.9)$ & $(0.9)$ \\
density & 19.3 & 22.1 & 21.3 \\
& $(11.4)$ & $(13.5)$ & $(12.8)$ \\
& 26.4 & 28.6 & 28.0 \\
& $(1.4)$ & $(1.3)$ & $(1.3)$ \\
\hline
\end{tabular}

\section{DISCUSSIONS}

In line with the previous study, the results showed that the largest food group is found in the grain group as a source of highfiber carbohydrates so that the glycemic index is low which results in a feeling of being full longer (21). The proportion of carbohydrates in each meal portion has the 
most share in low-income countries, poor economic conditions affect patterns and levels of household expenditure so that they cannot afford to buy a variety of food. The smallest food group at the age of 19-29 years old is the consumption of oily fruits and seeds. The results of this study were also supported by previous study that the consumption of oily fruits/seeds is the smallest food group because this was caused in part oils/fats consumed by individuals in the form of processed foods in this study were not counted in the oil/fat group (1). The smallest food group consumed by the age of 30-49 years was sugar. These finding in line with previous study that sugar consumption at this age is very low because they only consume food and drinks containing sugar such as caramel, chocolate, cakes and so on, on the other hand at this age are at risk of developing diseases related to excess sugar intake in the body so they choose not to consume pure sugar $(3,17)$.

Research in male aged 19-29 years showed that the average consumption of fat in Indonesian population was more than quarter of total daily energy consumption. Moreover, the result of the recent study revealed that prevalence of overweight among this aged group was almost ten percent. As the result that controlling the energy dence of diet and increasing physical activity were the essential issues to reach more better nutritional status in Indonesian male adult in 19-24 years old (20). In additon, the result of another showed that those aged group, which higher in body mass index were tent to had lower nutrient intakes in energy and protein (22).

Eating adequate and variety of food was essential to reach body requirement of nutrient. Indonesian adults consumed a lot of variety of food though it was still inadequate to get the required micronutrients (18). Thus, lack of knowledge in nutrition, the ability to purchase food, and the available to process the food could be reasons to explain that issue.

In demographic perspective, natural and semi-natural forest were positively associated with a larger number of nutritionally important food group in area in which limited for the poor in developing country. The research about forest and micronutrient-rich food consumption in Indonesia mentioned that most of dietary staples in this country were extremely low in zinc, vitamin A and iron while fruits, leafygreen vegetables, animal source foods contained higher densities of all three micronutrients. Moreover, social and cultural factors might also be affecting in dietary choices in Indonesian people which were not eating more fruits, vegetables, and animal source foods (10).

The higher the nutrient density value, the better the quality of the food consumed $(5,8,14)$. The results of the nutrient density calculation show that the food quality of 
adult male population in Indonesia still needs to be improved so that the nutrient density value is better. This is in line with previous studies which show that consumption of protein, vegetable and fruit sources is still low (4). This study was also in line with previous studies which showed that the density of protein, calcium, vitamin $A$ and vitamin $C$ in adults was still below the recommendation (14,19). The low consumption of vegetables, fruits and animal foods in the adult population in Indonesia was one of the factors that causes the low density of calcium and vitamin intake, especially vitamins $\mathrm{A}$ and $\mathrm{C}$.

\section{CONCLUSION}

The average food consumption of Indonesian adult male population is mostly from the grain's food group of $305.0 \mathrm{~g}$. The food group that was consumed the least by the adult population was oily seeds as much as $18.1 \mathrm{~g}$. The adequacy of energy, protein, calcium, iron, zinc, vitamin $\mathrm{A}$ and vitamin $\mathrm{C}$ were $81.4 \%, 108.3 \%, 105.5 \%, 159.4 \%$, $64.8 \%, 107.7 \%$ and $54.6 \%$, respectively. The nutrient density of protein, $\mathrm{Ca}, \mathrm{Zn}$, vitamin $A$ and vitamin $C$ were still under the recommendation. It means that food consumption quality of Indonesian adults needs to be improved. Considering that the adequacy of nutrients, especially micronutrients for the adult population of Indonesian, was still quite low, it is necessary to increase the consumption of animal foods, nuts, fruits and vegetables as food sources of micronutrients.

\section{ACKNOWLEDGMENT}

Thanks to the Health Research and Development Agency (Balitbangkes) of the Ministry of Health who has provided data so that this research can be carried out.

\section{REFERENCES}

1. Anwar, K., \& Hardinsyah. (2014). Konsumsi Pangan dan Gizi Serta Skor Pola Pangan Harapan pada Dewasa Usia 19-49 Tahun di Indonesia. Jurnal Gizi Dan Pangan, 9(1), 51-58.

2. Apriani, S., \& Baliwati, Y. F. (2011). Faktor-Faktor Yang Berpengaruh Terhadap Konsumsi Pangan Sumber Karbohidrat di Perdesaan dan Perkotaan. Jurnal Gizi Dan Pangan, 6(3), 200-207.

3. Berendsen, A. A. M., Kramer, C. S., \& de Groot, L. C. P. G. M. (2019). The Newly Developed Elderly NutrientRich Food Score Is a Useful Tool to Assess Nutrient Density in European Older Adults. Frontiers in Nutrition, 6 (August), 1-14. https://doi.org/10.3389/fnut.2019.001 19

4. Dewi, U. P., \& Dieny, F. F. (2013). Hubungan Antara Densitas Energi Dan Kualitas Diet Dengan Indeks Massa Tubuh (Imt) Pada Remaja. Journal of Nutrition College, 2(4), 447-457.

5. Drewnowski, A. (2005). Concept of a nutritious food: Toward a nutrient density score. American Journal of Clinical Nutrition, 82(4), 721-732.

6. Drewnowski, A., Dwyer, J., King, J. C., \& Weaver, C. M. (2019). A proposed nutrient density score that 
includes food groups and nutrients to better align with dietary guidance. Nutrition Reviews, 77(6), 404-416. https://doi.org/10.1093/nutrit/nuz002

7. Drewnowski, A., \& Fulgoni, V. L. (2014). Nutrient density: Principles and evaluation tools. American Journal of Clinical Nutrition, 99(5). https://doi.org/10.3945/ajen.113.0733 95

8. Ekaningrum, A. Y., Sukandar, D., \& Martianto, D. (2017). Keterkaitan Densitas Gizi, Harga Pangan, Dan Status Gizi Pada Anak Sekolah Dasar Negeri Pekayon 16 Pagi. Jurnal Gizi Dan Pangan, 12(2), 139-146. https://doi.org/10.25182/jgp.2017.12. 2.139-146

9. Fauzi, A. (2014). Analisis Densitas Asupan Zat Gizi dan Hubungannya dengan Status Gizi Siswa Sekolah Dasar di Kota Bogor. IPB University.

10. Ickowitz, A., Rowland, D., Powell, B., Salim, M. A., \& Sunderland, T. (2016). Forests, trees, and micronutrient-rich food consumption in Indonesia. PLoS ONE, 11(5), 1-15. https://doi.org/10.1371/journal.pone.0 154139

11. IOM. (2000). Dietary reference intakes for vitamin $C$, vitamin $E$, selenium, and carotenoids. Retrieved from

http://www.ncbi.nlm.nih.gov/books/ NBK225480/

12. IOM. (2001). Dietary Reference Intakes for Vitamin A, Vitamin K, Arsenic, Boron, Chromium, Copper, Iodine, Iron, Manganese, Molybdenum, Nickel, Silicon, Vanadium, and Zinc. Washington DC: National Academies Press.

13. IOM. (2011). Dietary Reference Intake for Calcium and vitamin D ( and H. B. D. V. A. Catharine Ross, Christine L. Taylor, Ann L. Yaktine, Ed.). Washington DC: National Academies Press.

14. Jayati, L. D., Madanijah, S., \& Khomsan, A. (2014). Pola Konsumsi
Pangan, Kebiasaan Makan, Dan Densitas Gizi Pada Masyarakat Kasepuhan Ciptagelar Jawa Barat. Penelitian Gizi Makanan, 37(1), 3342.

15. Lee, S. K., Park, H. K., \& Choi, Y. J. (2014). Nutritional standards for energy-dense low-nutrient density foods for children in Korea. Asia Pacific Journal of Clinical Nutrition, 23(1), 27-33. https://doi.org/10.6133/apjcn.2014.23 .1 .03

16. Miranti, A., Syaukat, Y., \& Harianto, N. (2016). Pola Konsumsi Pangan Rumah Tangga di Provinsi Jawa Barat. Jurnal Agro Ekonomi, 34(1), 67. https://doi.org/10.21082/jae.v34n1.20 16.67-80

17. Nguyen, P. H., Strizich, G., Lowe, A., Nguyen, H., Pham, H., Truong, T. V., ... Ramakrishnan, U. (2013). Food consumption patterns and associated factors among Vietnamese women of reproductive age. Nutrition Journal, 12(1), 1-11. https://doi.org/10.1186/1475-2891 12-126

18. Prasetyo, T. J., Hardinsyah, H., Baliwati, Y. F., \& Sukandar, D. (2018). The application of probability method to estimate micronutrient deficiencies prevalence of Indonesian adults. Jurnal Gizi Dan Pangan, 13(1), 17-26. https://doi.org/10.25182/jgp.2018.13. 1.17-26

19. Prasetyo, T. J., \& Khoiriani, I. N. (2020). Konsumsi Pangan dan Densitas Gizi Wanita Dewasa Usia 19-49 Tahun di Indonesia. Jurnal Dunia Gizi, 3(2).

20. Rifqi, M. A., \& Hardinsyah, H. (2016). Overweight Risk Factors Of Men Aged 19-29 Years In Indonesia.

21. Saputri, R., Lestari, L. A., \& Susilo, J. (2016). Pola konsumsi pangan dan tingkat ketahanan pangan rumah tangga di Kabupaten Kampar Provinsi Riau. Jurnal Gizi Klinik Indonesia, 12(3),

123. 
https://doi.org/10.22146/ijen.23110

22. Soraya, D., Sukandar, D., \& Sinaga, T. (2017). Hubungan pengetahuan gizi, tingkat kecukupan zat gizi, dan aktivitas fisik dengan status gizi pada guru SMP. Jurnal Gizi Indonesia (The Indonesian Journal of Nutrition), 6(1),
29-36.

https://doi.org/10.14710/jgi.6.1.29-36.

23. Henry, C. (2005). Basal metabolic rate studies in humans: measurement and development of new equations. Public Health Nutrition, 8(7a), 1133-1152. 